\title{
Effect of Caper Buds, Fruits and Leaves Addition on the Quality of Frozen Chicken Burger Patties
}

\author{
Hind S. Abu-Shama ${ }^{1}$
}

\begin{abstract}
This research aimed to produce chicken burger patties by adding different concentrations of caper buds, fruits and leaves powders $(1.5,2$ and $2.5 \%)$. The effect of caper additions on the produced chicken burger patties during frozen storage at $-18^{\circ} \mathrm{C}$ for 6 months was investigated. The obtained results showed that the caper powders were rich in total polyphenols and a good source of protein, fat, ash, crude fiber and total carbohydrates. However, the addition of caper powders to chicken burger patties led to improve the quality parameters such as; a decrease in cooking loss and shrinkage, an increase in water holding capacity (WHC) and cooking yield and exhibited good sensory properties and better acceptability. Furthermore, such addition caused improvement of the quality as that inhibited the microbial load, and enhanced the oxidative stability of chicken burger patties as the thiobarbituric acid values of chicken burgers during frozen storage at $18^{\circ} \mathrm{C}$ for 6 months decreased by increasing of the caper powders levels for all studied treatments compared with the control. Therefore, the research recommended utilizing caper powders in the manufacturing of chicken burger patties as an effective natural additive with both antioxidant and antibacterial activities to replace synthetic ones which are used in chicken meat products given their potential to enhance quality parameters and nutritional value of chicken burger patties.
\end{abstract}

Keywords: caper, chicken burger patties, quality parameters.

\section{INTRODUCTION}

Burgers are the world's most popular fast food, and they are made from either minced meat, minced chicken or fish paste with ingredients such as flour, oil, salt, pepper and some other preservatives (Abd.El Haleam, 2009 and Wong et al., 2012). During storage, the quality of these products is reduced, due to the oxidation of which cause degradation of organoleptic properties such as flavor, color, and texture (Keshk et al., 2008 and Salem et al., 2010).

This oxidation reaction is a complex process in which unsaturated fatty acids reacts with molecular oxygen to form free radicals and peroxides, which later are oxidized to aldehydes, ketones, and esters that are responsible for rancid flavor during storage. Rancidity in chilled or frozen storage can be reduced by the addition of antioxidants or by packing the meat in oxygen-impermeable films (Pettersen et al., 2004). Also, pathogenic bacteria can contaminate meat products and lead to the public health hazard and economic losses (Salem et al., 2010).

The use of synthetic antioxidants with high activity, such as propyl gallate, butylated hydroxyanisol (BHA), butylated hydroxytoluene (BHT), tertiary butyl hydroquinone (TBHQ), and nitric oxide from sodium nitrite have been widely used in meat and meat products (Weiss et al., 2010), but only a few can be used in food products because, it is controlled by regulatory laws of a country or international standards (Karre et al., 2013). In recent years, the demand for natural antioxidants has increased due to the potential toxicological effects of synthetic antioxidants (Shah et al., 2014).

The general trend in researches and studies now is to use plants as natural sources of antioxidants and antimicrobial due to their high content of bioactive compounds. These natural antioxidants from plants, in the form of extracts, have been obtained from different sources such as fruits (grapes, pomegranate, date and kinnow), vegetables, (broccoli, potato, drumstick, pumpkin, curry and nettle), herbs and spices ( rosemary, oregano, cinnamon, sage, thyme, mint, ginger and clove) and investigated to decrease the lipid oxidation (Mansour and Khalil, 2000; McCarthy et al., 2001; Nissen et al., 2004; Kanatt et al., 2007; Rojas and Brewer, 2007, 2008; Akarpat et al., 2008 and Wojciak et al., 2011).

In addition, to plant extracts direct incorporation of plant materials such as fruit pulp and seed powder has been investigated as potential antioxidants in meat and meat products (Karre et al., 2013). The protective effect of fruits has been attributed to phytochemicals, which are the non-nutrient plant compounds such as carotenoids, flavonoids, isoflavonoids, and phenolic acids. Phytochemicals have been found to possess huge functional activities, such as protecting against lipid oxidation, inhibiting cancer cell proliferation, and regulating inflammatory and immune response (Kumar et al., 2015).

Recently, increasing interest has been figured out in using natural ingredients in meat and meat products. 
Consumers have increasingly favoured meat products that contain natural additives due to concerns over adverse health effects of synthetic substances particularly some synthetic antioxidants. Oxidation has various detrimental effects on the quality of meat and meat products such as discoloration, development of rancid flavor and loss of functional properties which render the products unpalatable and unacceptable (Rather et al., 2016).

Caper (Capparis spinosa) has been introduced as a specialized culture in some countries for its antioxidant properties during the last four decades. It contains several chemically active and diverse secondary metabolites, in particular, phenolic substances, such as flavonoids, which are considered an important part of effective natural antioxidants. Studies have shown that there are more effective and active phenolic compounds such as quercetin and rutin, of which caper leaves, flowers, buds, and fruits are important sources (Inocencio et al., 2000). The phytochemicals in caper plant tissues that are responsible for the antioxidant capacity can largely be attributed to the phenolic, anthocyanins and other flavonoids compounds (Cao, 1997).

Therefore, this investigation intended to study the effect of caper buds, fruits and leaves powders addition to chicken burger patties as natural additives to enhance quality characteristics, nutritional value and extend the shelf life of chicken burger patties during frozen storage at $-18^{\circ} \mathrm{C}$ for 6 months.

\section{MATERIAL AND METHODS}

\section{MATERIALS:}

Plant:

- Buds, fruits and leaves of caper (Capparis spinosa L.) were collected in August 2016, from Wadi El Maghara, North Sinai, Egypt.

\section{Ingredients of burger:}

- Fresh chicken meat and beef back fat were purchased from a local market (Cairo, Egypt).

- Spices, and salt (sodium chloride) were obtained from a local market (Cairo, Egypt).

\section{Solvents and all chemicals:}

were obtained from El-Gomhoria Co. Cairo, Egypt.

\section{METHODS}

\section{Preparation of buds, fruits and leaves powders:}

Buds, fruits and leaves were dried in the open air and then ground into powder, by Lab. mixer (Monlinex $530,240 \mathrm{~V}$ ), and kept in polyethylene bags for further use.

\section{formulas of chicken burger patties:}

Minced chicken meat and other ingredients were used to prepare ten formulas as shown in Table 1.

Table 1. chicken burger patties formulas (\%)

\begin{tabular}{ccccccccccc}
\hline Ingredient (\%) & Control $(\mathbf{C})$ & $\mathbf{B}_{\mathbf{1}}$ & $\mathbf{B}_{\mathbf{2}}$ & $\mathbf{B}_{\mathbf{3}}$ & $\mathbf{F}_{\mathbf{1}}$ & $\mathbf{F}_{\mathbf{2}}$ & $\mathbf{F}_{\mathbf{3}}$ & $\mathbf{L}_{\mathbf{1}}$ & $\mathbf{L}_{\mathbf{2}}$ & $\mathbf{L}_{\mathbf{3}}$ \\
\hline Chicken meat & 64.14 & 64.14 & 64.14 & 64.14 & 64.14 & 64.14 & 64.14 & 64.14 & 64.14 & 64.14 \\
Fat & 15 & 15 & 15 & 15 & 15 & 15 & 15 & 15 & 15 & 15 \\
Salt & 2.87 & 2.87 & 2.87 & 2.87 & 2.87 & 2.87 & 2.87 & 2.87 & 2.87 & 2.87 \\
Iced water & 8.2 & 8.2 & 8.2 & 8.2 & 8.2 & 8.2 & 8.2 & 8.2 & 8.2 & 8.2 \\
Spices mixture & 2.59 & 2.59 & 2.59 & 2.59 & 2.59 & 2.59 & 2.59 & 2.59 & 2.59 & 2.59 \\
Starch & 3.34 & 3.34 & 3.34 & 3.34 & 3.34 & 3.34 & 3.34 & 3.34 & 3.34 & 3.34 \\
Onion powder & 3.22 & 3.22 & 3.22 & 3.22 & 3.22 & 3.22 & 3.22 & 3.22 & 3.22 & 3.22 \\
Garlic powder & 0.64 & 0.64 & 0.64 & 0.64 & 0.64 & 0.64 & 0.64 & 0.64 & 0.64 & 0.64 \\
Caper buds powder & - & 1.5 & 2 & 2.5 & - & - & - & - & - & - \\
Caper fruits powder & - & - & - & - & 1.5 & 2 & 2.5 & - & - & - \\
Caper leaves powder & - & - & - & - & - & - & - & 1.5 & 2 & 2.5 \\
\hline
\end{tabular}

C: Control B, F and L: buds, fruits and leaves of caper powders 


\section{Preparation of chicken burger patties:}

Each previous mixture (300) was blended for $5 \mathrm{~min}$ and shaped to circular burger patties of $9 \mathrm{~cm}$ diameter, $0.5 \mathrm{~cm}$ thickness and about $50 \mathrm{~g}$ weight. Each one was separated from the other by using polyethylene layer before packaging in polyethylene bags, and frozen at$18^{\circ} \mathrm{C}$ until using, (Ziprin et al.., 1981). The samples were stored for 3 and 6 months at $-18^{\circ} \mathrm{C}$.

\section{Chicken burger patties cooking:}

The burger samples were grilled in a preheated oven, at $163^{\circ} \mathrm{C}$ for $10 \mathrm{~min}$ to produce uniform browning without charring, according to the cooking method described by Baker et al. (1984).

\section{Quality of chicken burger Patties:}

\section{Cooking loss and cooking yield:}

Prepared chicken burger samples were weighed before and after cooking. The cooked samples were allowed to cool at room temperature, then were weighed and the cooking loss was calculated according to Naveena et al. (2008) as follows:

$$
\text { Cookingloss }(\%)=\frac{W R-W C \times 100}{W R}
$$

Where; WR: the weight of the uncooked chicken burger and WC: the weight of cooked chicken burger.

Cooking yield (\%) of different chicken burger samples was measured by subtracting cooking loss from 100.

Change of chicken burger patties diameter (Shrinkage):

Change in diameter (Shrinkage) of prepared chicken burger samples was measured for cooked samples as mentioned by George and Berry (2000) using the following equation:

\section{Shrinkage $(\%)=$ \\ Uncookeddiameter (cm)-Cookeddiameter (cm)X100 Uncookeddiameter $(\mathrm{cm})$}

\section{Water holding capacity (WHC):}

Water-holding capacity (WHC) of prepared chicken burger samples was measured according to the method described by Honikel (1998) as follows: $0.3 \mathrm{~g}$ of the chicken burger was carefully flattened in a glass plate and covered with ashless filter paper (Whatman No. 41) then, pressed for 10 min using a mass of one $\mathrm{kg}$ weight.
After pressing, two zones were formed on the filter paper; the outer zones resulted from the secretion of water from samples and the internal zones resembled the area of pressed meat. The formed two zones were measured by a planimeter (KOIZUMI Digital Planimeter, PLACOM KP-90, NO.18790 - Made in Japan). Results were presented in $\left(\mathrm{cm}^{2} / 0.3 \mathrm{~g}\right.$ sample).

\section{Analytical Methods:}

\section{Gross chemical composition:}

- Moisture, protein $(\mathrm{N} \times 6.25)$, ether extract (petroleum ether 40-60/16h), fiber, ash were estimated according to A.O.A.C. (2000), and carbohydrates were calculated by difference.

- Polyphenols content was determined as total polyphenols according to Swain and Hillis (1959), and all values were expressed as average (mg of Gallic Acid Equivalents/g on dry base).

\section{Determination of thiobarbituric acid (TBA):}

Lipid oxidation of the chicken burger samples was determined using the distillation of 2-thiobarbituric acid (TBA) according to Harold et al. (1987). The absorbance (A) was measured against a blank at $538 \mathrm{~nm}$ using a digital spectrophotometer (UV-VIS spectrophotometer Shimadzu Model, 1240) and TBA value as $\mathrm{mg}$ malonaldehyde/ $\mathrm{Kg}$ sample was calculated by multiplying the absorbance (A) by 7.8.

\section{Microbiological assay:}

Total bacterial counts of all samples were determined by the plate count technique on nutrient agar medium according to the procedure of American Public Health Association "APHA" (1976) and Difco (1984). The plates were incubated at $37^{\circ} \mathrm{C}$ for $48 \mathrm{hr}$. The procedure of Difco was followed to assay yeasts and molds occurrence by using potato dextrose agar medium. Results were expressed as (cfu/gm.).

\section{Sensory evaluation of chicken burger patties:}

Sensory characteristics evaluation of the produced chicken burger samples contained different ratios of caper buds, fruits and leaves powders were carried out at zero time. Cooked chicken burger patties were left to cool at room temperature for $15 \mathrm{~min}$ before being subjected to organoleptic evaluation as cited by Basker (1988). The cooked burger samples were evaluated by ten panelists from the staff of the Agriculture Industrialization Unit, Desert Research Center. Panelists were asked to evaluate different cooked burger treatments for texture, taste, color, odor, tenderness, juiciness and overall acceptability on a 10 points scale. 


\section{Statistical analysis}

A completely randomized experimental design was selected to define the effect of the treatments, all determinations were carried out in triplicate and data were reported as mean. Significant differences $(\mathrm{p}<0.05)$ were calculated using Duncan multiple range tests, as reported by Steel and Torrie (1980).

\section{RESULTS AND DISCUSSION}

\section{Chemical composition of caper powders:}

Caper buds, fruits and leaves powders, were chemically analyzed for moisture, protein; fat, ash, crude fiber and total carbohydrates. The data are shown in Table (2).
The data are given in Table (2) show thatthe highest phenolic content was found in leaves extract $(39.97 \mathrm{mg}$ Gallic acid/g sample) followed by buds extract ( 38.33 $\mathrm{mg} / \mathrm{g}$ ) and the lowest was in fruits extract $(34.81 \mathrm{mg} / \mathrm{g})$. These results are similar to those of Tlili et al. (2010) who showed that caper leaves contain a higher level of phenolic compounds than buds.

Effect of caper additions on Cooking quality and Sensory evaluation of cooked chicken burger patties:

Cooking quality of cooked chicken burger patties:

Cooking loss, shrinkage and cooking yield (\%) of differently prepared chicken burger samples contained different ratios of caper buds, fruits and leaves powders are presented in Table (3).

Table 2. Chemical composition (\%) and total polyphenols content of caper powders (as dry matter)

\begin{tabular}{cccccccc}
\hline Sample & Moisture & Protein & Fat & Ash & Crude fiber & $\begin{array}{c}\text { Total } \\
\text { carbohydrates }\end{array}$ & $\begin{array}{c}\text { Total polyphenols (mg } \\
\text { Gallic acid/g })\end{array}$ \\
\hline Buds & $3.46^{\mathrm{b}}$ & $26.14^{\mathrm{a}}$ & $14.89^{\mathrm{b}}$ & $9.73^{\mathrm{b}}$ & $8.08^{\mathrm{b}}$ & $37.69^{\mathrm{b}}$ & $38.33^{\mathrm{a}}$ \\
Fruits & $4.19^{\mathrm{b}}$ & $15.92^{\mathrm{c}}$ & $16.94^{\mathrm{a}}$ & $6.63^{\mathrm{c}}$ & $13.81^{\mathrm{a}}$ & $42.51^{\mathrm{a}}$ & $34.81^{\mathrm{b}}$ \\
Leaves & $6.93^{\mathrm{a}}$ & $17.38^{\mathrm{b}}$ & $18.44^{\mathrm{a}}$ & $21.84^{\mathrm{a}}$ & $8.70^{\mathrm{b}}$ & $26.71^{\mathrm{c}}$ & $39.97^{\mathrm{a}}$ \\
\hline L.S.D & 0.934 & $0.334^{\mathrm{b}}$ & 1.580 & 1.179 & 1.262 & 1.284 & 1.520 \\
\hline
\end{tabular}

Values bearing the same superscript within the same column are not significantly different $(\mathrm{P}>0.05)$.

Table 3. Percentage cooking loss, shrinkage and cooking yield of cooked chicken burger patties prepared using different levels of caper buds, fruits and leaves powders

\begin{tabular}{cccc}
\hline Treatments & Cooking loss\% & Shrinkage \% & Cooking Yield \% \\
\hline Control (C) & $26.28^{\mathrm{a}}$ & $23.00^{\mathrm{a}}$ & $73.73^{\mathrm{d}}$ \\
$\mathrm{B}_{1}$ & $23.22^{\mathrm{bcd}}$ & $13.27^{\mathrm{b}}$ & $76.78^{\mathrm{bc}}$ \\
$\mathrm{B}_{2}$ & $21.88^{\mathrm{d}}$ & $12.25^{\mathrm{b}}$ & $78.12^{\mathrm{b}}$ \\
$\mathrm{B}_{3}$ & $20.09^{\mathrm{e}}$ & $10.10^{\mathrm{c}}$ & $79.91^{\mathrm{a}}$ \\
$\mathrm{F}_{1}$ & $24.72^{\mathrm{b}}$ & $13.13^{\mathrm{b}}$ & $75.28^{\mathrm{cd}}$ \\
$\mathrm{F}_{2}$ & $24.52^{\mathrm{bc}}$ & $11.96^{\mathrm{b}}$ & $75.48^{\mathrm{c}}$ \\
$\mathrm{F}_{3}$ & $23.49^{\mathrm{bcd}}$ & $9.42^{\mathrm{c}}$ & $76.51^{\mathrm{bc}}$ \\
$\mathrm{L}_{1}$ & $23.32^{\mathrm{bcd}}$ & $13.68^{\mathrm{b}}$ & $76.68^{\mathrm{bc}}$ \\
$\mathrm{L}_{2}$ & $23.02^{\mathrm{cd}}$ & $12.24^{\mathrm{b}}$ & $76.98^{\mathrm{bc}}$ \\
$\mathrm{L}_{3}$ & $22.48^{\mathrm{d}}$ & $12.00^{\mathrm{b}}$ & $77.52^{\mathrm{b}}$ \\
\hline L.S.D & 1.478 & $1.822^{\mathrm{b}}$ & 1.664
\end{tabular}

Values bearing the same superscript within the same column are not significantly different $(\mathrm{P}>0.05)$. 
The addition of caper powders led to a significant $(\mathrm{P}$ $\leq 0.05$ ) reduction in cooking loss and shrinkage of all treated chicken burger samples, especially at a level of 2.5\% compared with the control. Concerning the cooking loss, the highest decrement was recorded for $\mathrm{B}_{3}$ which reached $20.096 \%$,

Shrinkage is considered one of the most important parameters of quality changes that occur in burgers during the frying process due to the protein denaturation and squeezing out fat and water from burger patties (Oroszvári et al., 2005, Alakali et al., 2010 and AlJuhaimi et al., 2016).

The data in Table (3) reveal that, there was a significant $(\mathrm{P} \leq 0.05)$ decrease in the percentage of shrinkage among chicken burger samples containing different ratios of caper buds, fruits and leaves powders compared with the control. On the other hand, the highest value was found in control $(23 \%)$ and the lowest value was in chicken burger patty $\mathrm{F}_{3}$ with $2.5 \%$ fruits powder $(9.42 \%)$. These results agree with $\mathrm{Badr}$ and El-Waseif (2017) who found that the percentage of diameter shrinkage in beef burger patties was found to decrease continuously with increasing the addition levels of caper seeds powder.

The addition of caper buds, fruits and leaves powders to chicken burger patties resulted in a significantly slight higher $(\mathrm{P}<0.05)$ cooking yield compared to the control sample which had recorded the lowest cooking yield (73.726\%). On the other hand, chicken burger sample $\mathrm{B}_{3}$ which contained $2.5 \%$ buds powder had the highest percentage (79.91\%) followed by both $\mathrm{B}_{2}$ and $\mathrm{L}_{3}(78.12$ and $77.52 \%)$ for buds powder $2 \%$ and leaves powder $2.5 \%$, respectively. Thus, improvement cooking yield could be attributed to the stabilizing role of polyphenolic compounds (Reihani et al., 2014). Similar results have been obtained by Gok et al. (2011) who reported a significant increase $(\mathrm{P}<0.05)$ in the cooking yield with the addition of poppy seed into beef burgers. Low cooking yield in the control beef patties could be associated with moisture and fat loss from the beef patties during cooking (Serdaroglu \& Degirmencioglu, 2004).

Sensory evaluation of cooked chicken burger patties:

Average sensory panel scores of texture, taste, color, odor, tenderness, Juiciness and overall acceptability for chicken burger patties containing caper buds, fruits and leaves powders at different levels are shown in Table (4).

The results in Table (4) showed that slight significant differences between the control and all other treated chicken burger samples. Chicken burger patty with $2.5 \%$ buds' powder $\left(\mathrm{B}_{3}\right)$ had the highest score of texture (8.6), while this process with $1.5 \%$ leaves powder $\left(\mathrm{L}_{1}\right)$ recorded the lowest score (8.1). Concerning the taste, the highest score (8.6) was for $\mathrm{F}_{2}$ (2\% fruits powder), which was considered significantly high compared with other treatments except for the control and $F_{1}$. Regarding color results, it could be noticed that all studied treatments had a slight significant negative effect on sample color in comparison with the control except $\mathrm{B}_{3}$. Also, all studied treatments led to a decrease significantly both of odor and tenderness compared with the control. Concerning juiciness, it could be observed that only $B_{3}$ and $F_{1}$ had no negative effect on juiciness in respect to the control. At the same time, $F_{1}(1.5 \%$ fruits powder) recorded the highest score in overall acceptability followed by $\mathrm{F}_{2}$ (2\% Fruits powder) and then $\mathrm{B}_{3}(2.5 \%$ buds powder) with recoded values 8.7 , 8.6 and 8.4 , respectively, compared with the control sample (8.3). On the other hand, chicken burger patty with $1.5 \%$ leaves powder $\left(\mathrm{L}_{1}\right)$ recorded the lowest score in overall acceptability (7.8).

Table 4. Sensory evaluation of cooked chicken burger patties containing different concentrations of caper buds, fruits and leaves powders

\begin{tabular}{|c|c|c|c|c|c|c|c|}
\hline Treatments & $\begin{array}{c}\text { Texture } \\
\text { (10) }\end{array}$ & $\begin{array}{l}\text { Taste } \\
\text { (10) }\end{array}$ & $\begin{array}{l}\text { Color } \\
\text { (10) }\end{array}$ & $\begin{array}{c}\text { Oder } \\
\text { (10) }\end{array}$ & $\begin{array}{c}\text { Tenderness } \\
\text { (10) }\end{array}$ & $\begin{array}{c}\text { Juiciness } \\
\text { (10) }\end{array}$ & $\begin{array}{c}\text { Overall } \\
\text { Acceptability (10) }\end{array}$ \\
\hline $\mathrm{C}$ (Control) & $8.5^{\mathrm{ab}}$ & $8.5^{\mathrm{a}}$ & $8.8^{\mathrm{a}}$ & $8.9^{a}$ & $8.5^{\mathrm{a}}$ & $8.6^{\mathrm{a}}$ & $8.3^{\mathrm{bcd}}$ \\
\hline $\mathrm{B}_{1}$ & $8.3^{\mathrm{bc}}$ & $8.1^{b c}$ & $8.4^{\text {bcd }}$ & $8.3^{\mathrm{d}}$ & $8.1^{\mathrm{b}}$ & $8.2^{\mathrm{bc}}$ & $8.1^{\mathrm{cde}}$ \\
\hline $\mathrm{B}_{2}$ & $8.3^{\mathrm{bc}}$ & $7.3^{\mathrm{d}}$ & $8.5^{\mathrm{bc}}$ & $8.3^{d}$ & $7.9^{b}$ & $7.9^{\mathrm{de}}$ & $8.0^{\mathrm{de}}$ \\
\hline $\mathrm{B}_{3}$ & $8.6^{\mathrm{a}}$ & $7.3^{\mathrm{d}}$ & $8.6^{\mathrm{ab}}$ & $8.6^{b c}$ & $8.1^{\mathrm{b}}$ & $8.4^{\text {ab }}$ & $8.4^{\mathrm{ab}}$ \\
\hline $\mathrm{F}_{1}$ & $8.4^{\mathrm{ab}}$ & $8.3^{\mathrm{ab}}$ & $8.3^{\text {cde }}$ & $8.2^{\mathrm{d}}$ & $7.9^{b}$ & $8.4^{\mathrm{ab}}$ & $8.7^{\mathrm{a}}$ \\
\hline $\mathrm{F}_{2}$ & $8.4^{\mathrm{ab}}$ & $8.6^{\mathrm{a}}$ & $8.1^{\text {ef }}$ & $8.7^{b}$ & $7.8^{\mathrm{b}}$ & $8.1^{\mathrm{cd}}$ & $8.6^{\mathrm{ab}}$ \\
\hline $\mathrm{F}_{3}$ & $8.3^{\mathrm{bc}}$ & $8.1^{\mathrm{bc}}$ & $8.4^{\text {bcd }}$ & $8.6^{b c}$ & $7.9^{b}$ & $7.7^{\mathrm{e}}$ & $8.2^{\mathrm{cd}}$ \\
\hline $\mathrm{L}_{1}$ & $8.1^{\mathrm{c}}$ & $7.9^{\mathrm{c}}$ & $8.3^{\mathrm{cde}}$ & $8.3^{\mathrm{d}}$ & $8.0^{\mathrm{b}}$ & $8.0^{\mathrm{cd}}$ & $7.8^{\mathrm{e}}$ \\
\hline $\mathrm{L}_{2}$ & $8.3^{\mathrm{bc}}$ & $7.9^{\mathrm{c}}$ & $7.9^{\mathrm{f}}$ & $8.3^{\mathrm{d}}$ & $7.9^{b}$ & $7.9^{\mathrm{de}}$ & $8.1^{\mathrm{cde}}$ \\
\hline $\mathrm{L}_{3}$ & $8.4^{\mathrm{ab}}$ & $8.0^{\mathrm{bc}}$ & $8.2^{\mathrm{de}}$ & $8.4^{\mathrm{cd}}$ & $8.0^{\mathrm{b}}$ & $8.1^{\mathrm{cd}}$ & $8.3^{\mathrm{bcd}}$ \\
\hline L.S.D & 0.184 & 0.335 & 0.201 & 0.208 & 0.307 & 0.248 & 0.294 \\
\hline
\end{tabular}

Values bearing the same superscript within the same column are not significantly different $(\mathrm{P}>0.05)$. 
Effect of caper additions on chemical composition, water holding capacity, TBA value and microbial loads of uncooked chicken burger patties during frozen storage at $-18^{\circ} \mathrm{C}$ for 6 months:

Proximate chemical composition of uncooked chicken burger patties:

The chemical composition (moisture, protein, fat, ash, and total carbohydrate) of chicken burger patties containing different ratios of caper buds, fruits and leaves powders was determined during frozen storage at $-18^{\circ} \mathrm{C}$ for 6 months. The results showed in Fig.1,2,3,4 and 5 .

In Fig.1, the results illustrated that there was a substantial increase in moisture content of chicken burger patties containing different ratios of caper buds, fruits and leaves powders compared with the control. The moisture content increased with increasing the level of caper powders ratios at zero time. Where, the chicken burger sample $\mathrm{L}_{3}$ (which contained $2.5 \%$ caper leaves powder) recorded the highest moisture content $58.511 \%$ compared to other studied chicken burger samples. The moisture increment as a result of caper powders addition could be attributed to the polyphenol compounds that could act as stabilizers and reduce moisture loss during storage and defrosting, accordingly increase the waterbinding capacity and The moisture content (Madhan et al., 2005 and Zaki et al., 2013). The results in the same Fig. 1 showed a gradual increase in moisture content of all chicken burger samples with progressing of the storage period.

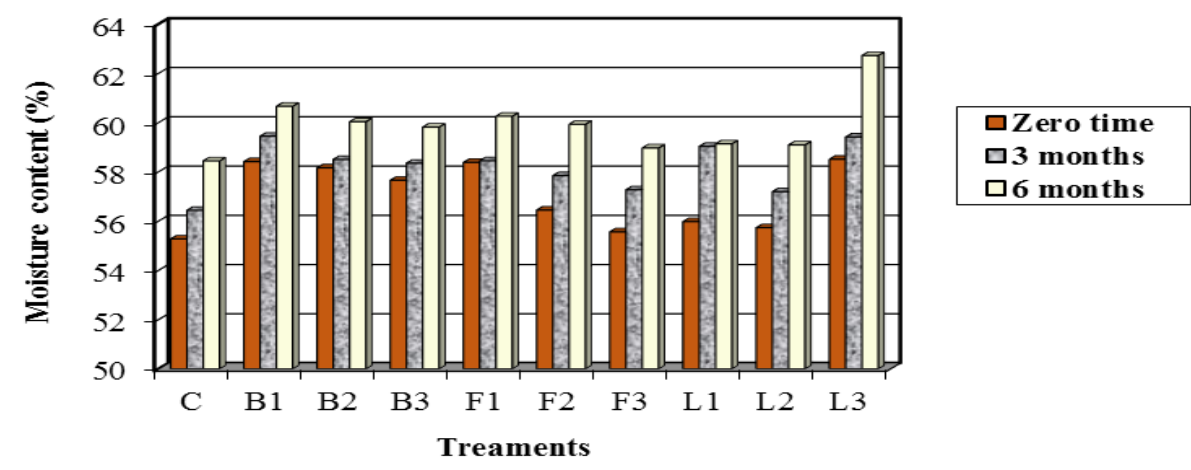

Fig. 1. Moisture content of chicken burger as affected by addition of different concentrations of caper buds, fruits and leaves powder during frozen storage

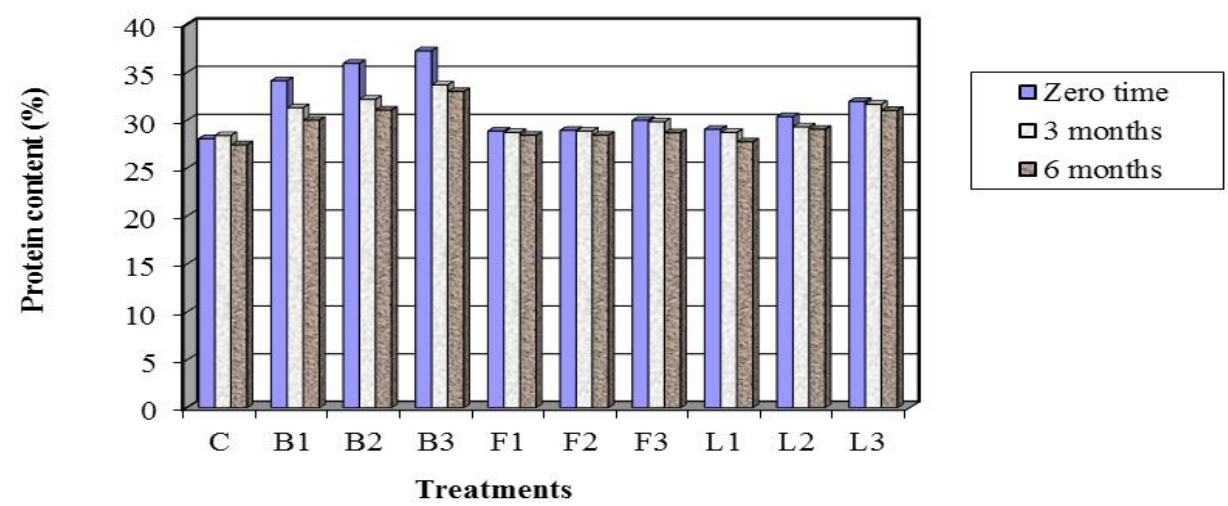

Fig. 2. Protein content of chicken burger as affected by addition of different concentrations of caper buds, fruits and leaves powder during frozen storage 
Data in Fig. 2, show the protein content of chicken burger patties as affected by the addition of different concentrations of caper buds, fruits and leaves. Protein content was gradually increased in all chicken burger samples with increasing the level of caper buds, fruits and leaves powders compared with the control. Whereas, the chicken burger samples which contained caper buds powder in different ratios were the highest followed by caper leaves and fruits powders which may be attributed to the higher protein content of buds powders. Meanwhile, a slight gradual decrease in protein content was noticed with the progressing of the storage period. The decrease in protein content of treated chicken burger samples during the storage period could be explained by the loss of soluble protein associated with the loss of water content of the burger. Similar findings were reported by Taludkar and Sharma (2009). They observed a decrease in the protein content of chicken meat patties incorporated with wheat and oat bran.

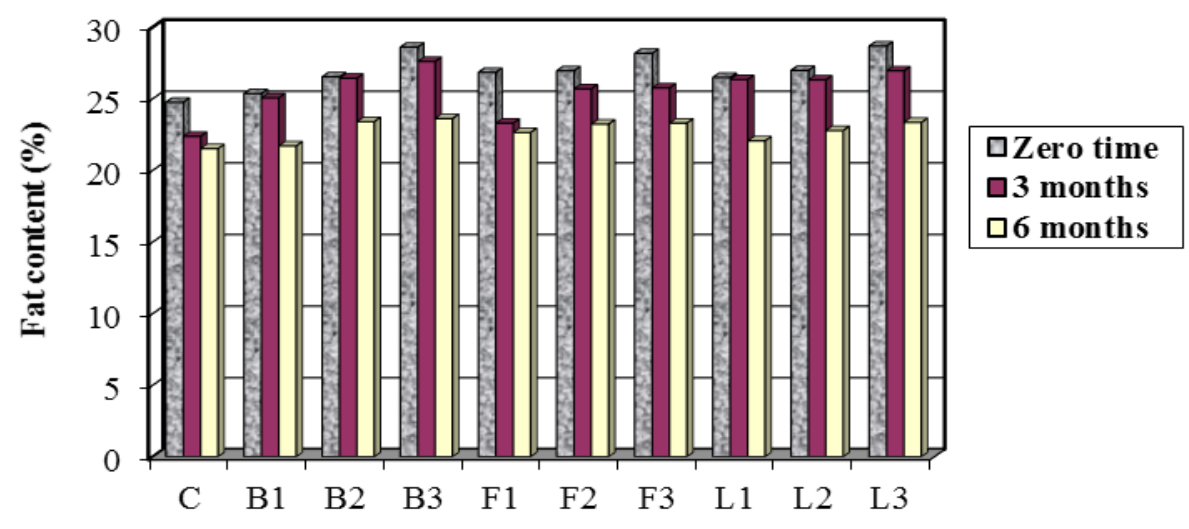

Treatments

Fig. 3. Fat content of chicken burger as affected by addition of different concentrations of caper buds, fruits and leaves powder during frozen storage

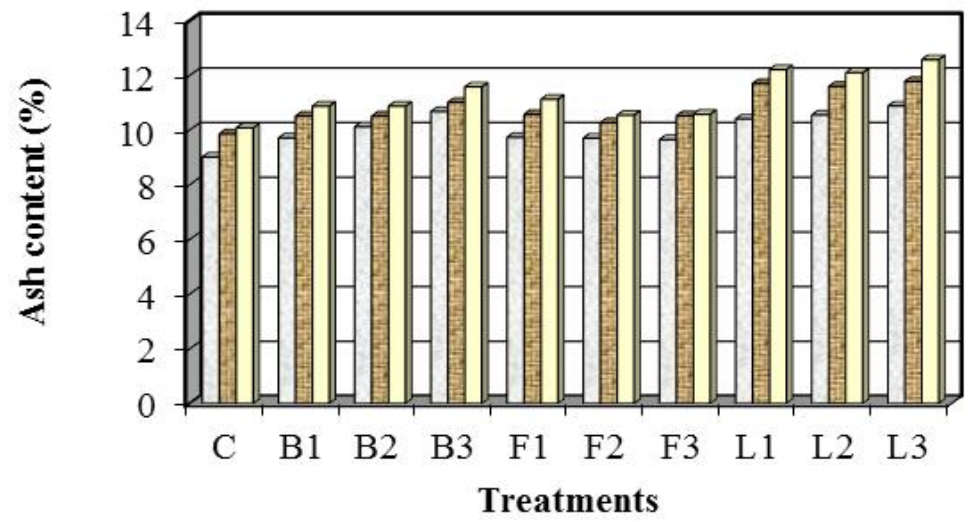

\section{口Zero time \\ a3 months \\ $\square 6$ months}

Fig.4. Ash content of chicken burger as affected by addition of different concentrations of caper buds, fruits and leaves powder during frozen storage 
Results in Fig. 3, show a slight significant $(P \leq 0.05)$ increase in the fat of chicken burger patties containing the caper buds, fruits and leaves powders with increasing the levels of additions in all studied treatments when compared with the control. On the contrary, as the storage period increased, the fat content was significantly $(P \leq 0.05)$ decreased, while, the control chicken burger sample showed the lowest fat content and the highest decrease was observed at the end of the storage period (6 months).

The data in Fig. 4, indicate that, total ash content exhibited a gradual increase in all chicken burger samples with increasing the level of caper buds, fruits and leaves powders compared with the control. This may be due to the higher mineral content of caper powders. At the same time, as the storage period increased, the ash content was slight significantly $(P \leq$ 0.05 ) increased for all studied chicken burger samples, but the highest increment at the end of the frozen storage period was recorded for chicken burger patties processed with leaves powder compared with the control and other treated samples.

From Fig. 5, it could be seen that total carbohydrate contents of chicken burger patties containing the caper buds, fruits and leaves powders recorded a significant decrease $(\mathrm{P} \leq 0.05)$ with increasing the caper level additions in all treated samples, when compared with the control. All chicken burger patties which were prepared with different levels of caper buds, fruits and leaves powders had a considerable amount of total carbohydrates content and the lowest was possessed for chicken burger patty produced by adding $2.5 \%$ buds powder $\mathrm{B}_{3}$ when compared with the control and other studied treatments at the beginning of storage period (Zero time). At the same time, as the storage period was extended, the total carbohydrates content of all studied chicken burger samples showed a slight significant $(P \leq$ 0.05 ) increase.

From the findings of the proximate analysis, it appears the chicken burger patties containing different ratios of caper buds, fruits and leaves powders had a good nutritional quality during frozen storage at $-18^{\circ} \mathrm{C}$ for 6 months,

\section{Water holding capacity of chicken burger patties:}

Water-holding capacity (WHC) is one of the major quality properties of fresh meat as it affects some major characteristics such as potential drip loss, technological quality, appearance and sensory properties (Das et al., 2011).Water holding capacity (WHC) of uncooked chicken burger patties prepared using different ratios of caper buds, fruits and leaves powder during 6 months frozen storage at $-18^{\circ} \mathrm{C}$ was determined as the area of released water in $\mathrm{cm}^{2} / 0.3 \mathrm{~g}$ sample and the results are shown in Table (5).

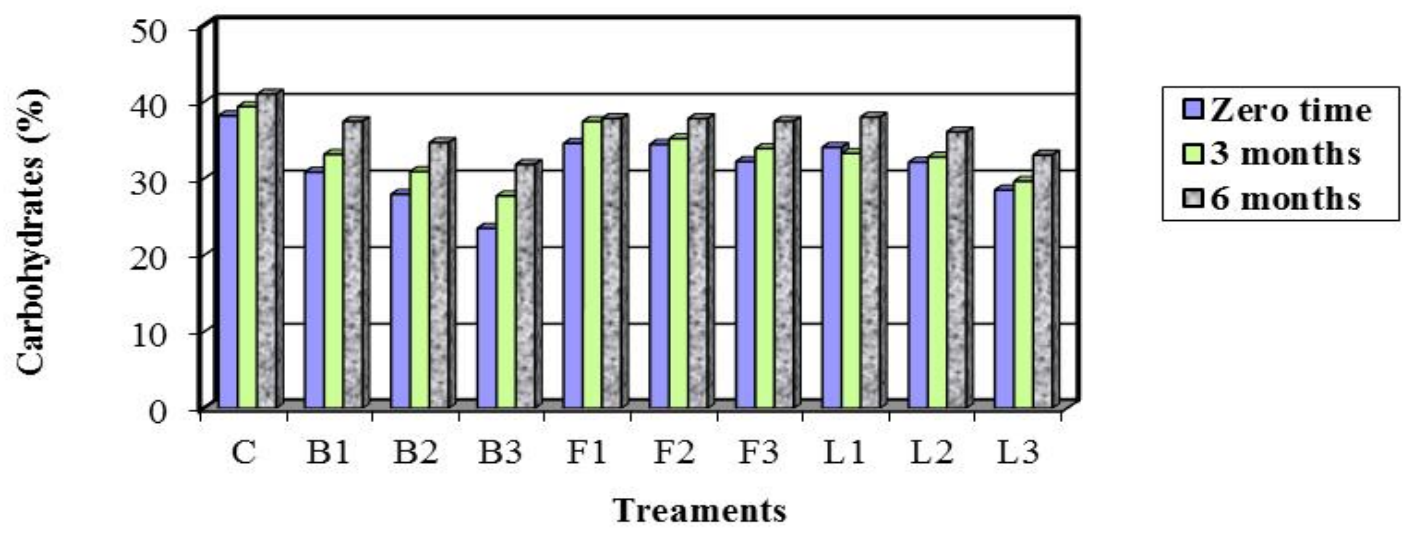

Fig. 5. Total carbohydrates content of chicken burger as affected by addition different concentrations of caper buds, fruits and leaves powder during frozen storage 
Table 5. Change in water holding capacity of uncooked chicken burger patties prepared with different ratios of caper buds, fruits and leaves powder during 6 months frozen storage at $-18^{\circ} \mathrm{C}$

\begin{tabular}{|c|c|c|c|c|}
\hline \multirow{2}{*}{ Treatments } & \multicolumn{3}{|c|}{ Water Holding Capacity $\left(\mathrm{cm}^{2} / 0.3 \mathrm{~g}\right)$} & \multirow{2}{*}{ L.S.D } \\
\hline & Zero time & 3 months & 6 months & \\
\hline Control (C) & $4.95^{\mathrm{aB}}$ & $5.20^{\mathrm{aA}}$ & $5.40^{\mathrm{aA}}$ & 0.237 \\
\hline $\mathrm{B}_{1}$ & $3.80^{\mathrm{cB}}$ & $3.95 \mathrm{de} A \mathrm{~B}$ & $4.10^{\mathrm{dA}}$ & 0.173 \\
\hline $\mathrm{B}_{2}$ & $3.00^{\mathrm{eC}}$ & $3.75^{\mathrm{fB}}$ & $4.00 \mathrm{dA}$ & 0.163 \\
\hline $\mathrm{B}_{3}$ & $3.95^{\mathrm{cC}}$ & 4. $05^{\mathrm{dB}}$ & 4. $15^{\mathrm{dA}}$ & 0.081 \\
\hline $\mathrm{F}_{1}$ & $3.90^{\mathrm{cC}}$ & $4.85^{\mathrm{bB}}$ & $5.15^{\mathrm{bA}}$ & 0.156 \\
\hline $\mathrm{F}_{2}$ & $3.30 \mathrm{dC}$ & $3.85^{\mathrm{efB}}$ & $4.75^{\mathrm{cA}}$ & 0.202 \\
\hline $\mathrm{F}_{3}$ & $3.10^{\mathrm{eC}}$ & 3.80 efB & $4.04 \mathrm{dA}$ & 0.124 \\
\hline $\mathrm{L}_{1}$ & $3.45 \mathrm{dC}$ & $3.85^{\mathrm{efB}}$ & $4.65^{\mathrm{cA}}$ & 0.215 \\
\hline $\mathrm{L}_{2}$ & $4.25^{\mathrm{bB}}$ & $4.50^{\mathrm{cB}}$ & $5.15^{\mathrm{bA}}$ & 0.264 \\
\hline $\mathrm{L}_{3}$ & $3.80^{\mathrm{cC}}$ & $4.55^{\mathrm{cB}}$ & $4.70^{\mathrm{cA}}$ & 0.141 \\
\hline L.S.D & 0.152 & 0.163 & 0.144 & \\
\hline
\end{tabular}

Values bearing the same small letter within the same column (effect of treatments) are not significantly different $(\mathrm{P}>0.05)$.

Values bearing the same capital letter within the same row (effect of storage period) are not significantly different $(\mathrm{P}>0.05)$.

WHC of meat is considered as an important factor that affects tenderness, thawing drip and cooking loss of meat (Hamm, 1986).

With the fact that the best water holding capacity is the lowest value, it was noticed that, WHC increased in treated chicken burger samples prepared with different ratios of caper buds, fruits and leaves powders compared to the control sample, where the control sample recorded the lowest significant WHC. On the other hand, water holding capacity (WHC) decline continuously with the progression of the storage period. Where, water holding capacity of the control sample decreased from $4.95 \mathrm{~cm}^{2} / 0.3 \mathrm{~g}$ at zero time of storage to be $5.2 \mathrm{~cm}^{2} / 0.3 \mathrm{~g}$ at the end of frozen storage. Meanwhile, the addition of $2.5 \%$ caper fruits powder to $\mathrm{F}_{3}$ chicken burger sample led to the highest improving WHC at zero, three and six months of storage (3.1, 3.8 and $4.04 \mathrm{~cm}^{2} / 0.3 \mathrm{~g}$ respectively) followed by the sample $\mathrm{B}_{2}$ contained $2 \%$ caper buds powder $(3.0,3.75$ and 4.0 $\mathrm{cm}^{2} / 0.3 \mathrm{~g}$, respectively) comparing with the control sample, and other chicken burger patties.

From these results, it could be noticed that the samples containing caper buds, fruits and leaves powders had a high ability to retain water where, the increasing of addition levels in chicken burger patties increased the WHC which reflect increasing the ability of chicken meat protein to holding water. The increase of WHC can be explained by increases in the water absorption capacity of protein and the swelling of the fiber (Rodriguez-Ambriz et al., 2008 and Ali et al.,2011).

TBA value of uncooked chicken burger patties:

The TBARS value has been widely used to determine the degree of lipid oxidation (Klangpetch et al., 2016) and used as an index of lipid oxidation in meat products during storage (Fernández-López et al.,
1997 and Pearson, 1991). The changes in TBA values of produced chicken burger patties with different concentrations of caper buds, fruits and leaves powders during frozen storage $\left(-18^{\circ} \mathrm{C}\right)$ at zero time, 3 and 6 months were determined and the results are presented in Fig. (6),

Data in Fig. 6, shows the changes in thiobarbituric acid (TBA) of studied chicken burger patties prepared by addition of different concentrations of caper buds, fruits and leaves powders during frozen storage $\left(-18^{\circ} \mathrm{C}\right)$ at zero time, 3 and 6 months.

From the Fig., it can be observed that there was a gradual increase in TBA values during frozen storage of chicken burger patties, all samples had a low value of TBA at zero time, whereas, $\mathrm{F}_{3}$ sample $(2.5 \%$ caper fruit powder) had the lowest value of TBA $(0.019 \mathrm{mg}$ malondialdehyde/Kg). Meanwhile, increasing TBA values was more pronounced in the control sample $\mathrm{C}$ compared with others during the storage period. At the end of frozen storage (6 months), the highest reduction of lipid oxidation (TBA) had been recorded in $\mathrm{L}_{1}(0.090$ $\mathrm{mg} / \mathrm{kg}$ ) followed by $\mathrm{F}_{3}$ which was recorded $(0.094$ $\mathrm{mg} / \mathrm{kg}$ ) comparing with the control sample which was reached $0.273 \mathrm{mg} / \mathrm{kg}$. This may be due to that, buds, fruits and leaves of caper are rich in antioxidants (polyphenols and flavonoids) with high activity and are unusually resistant to the development of rancidity. These results agree with Kumar et al. (2015) who reported that the protective effect of fruits has been attributed to phytochemicals, which are the non-nutrient plant compounds such as carotenoids, flavonoids, isoflavonoids and phenolic acids. Phytochemicals have been found to possess huge functional activities, such as protecting against lipid oxidation. 


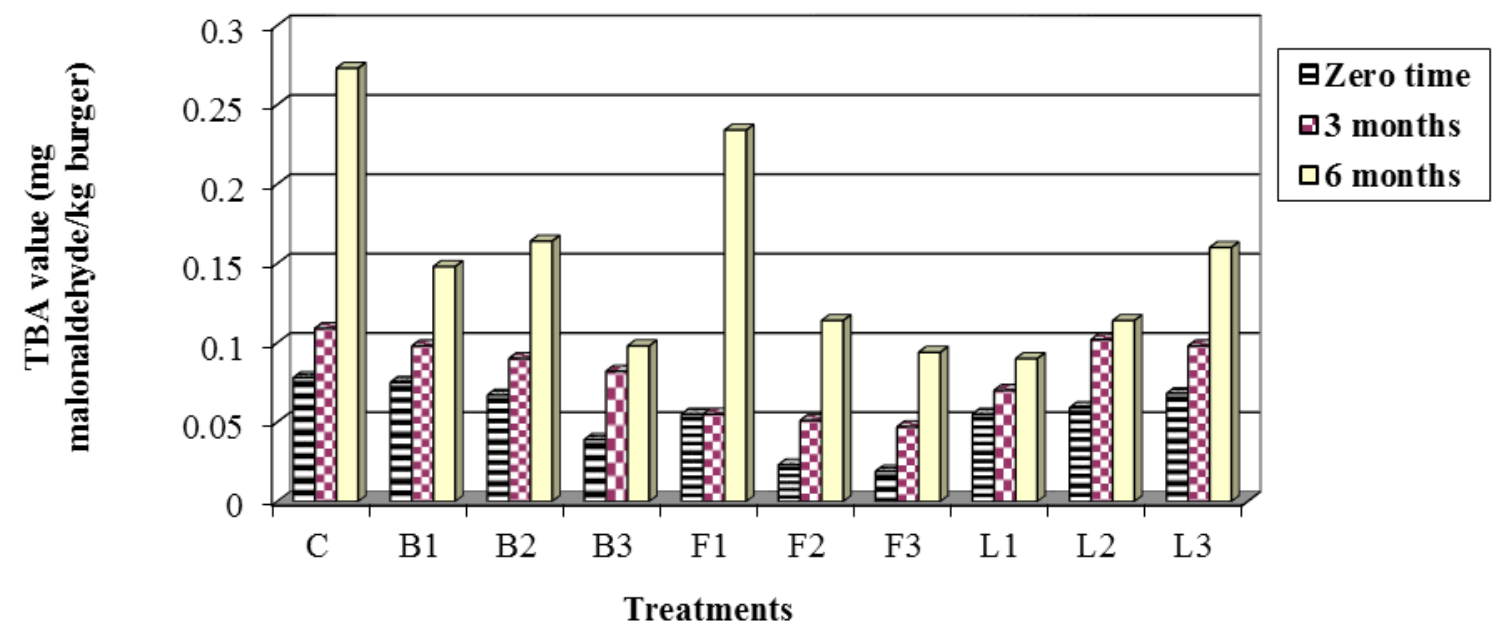

Fig. 6. TBA value (mg malonaldehyde/kg burger) of chicken burger samples during frozen storage

Microbial loads of uncooked chicken burger patties:

Microbial loads including total bacterial count (TBC), mold and yeast counts (M\&Y)] of chicken burger patties and the effects of adding caper buds, fruits and leaves powders during frozen storage $\left(-18^{\circ} \mathrm{C}\right)$ at zero time, 3 and 6 months were determined and the results are presented in Table (6).

Table 6. Total bacterial count (TBC), mold and yeast counts (M\&Y) of uncooked chicken burger patties with different concentrations of caper buds, fruits and leaves powders during frozen storage $\left(-18{ }^{\circ} \mathrm{C}\right)$ at zero time, 3 and 6 months

\begin{tabular}{|c|c|c|c|c|c|c|}
\hline \multirow{3}{*}{ Treatments } & \multicolumn{6}{|c|}{ Storage period (months) } \\
\hline & Zero time & 3 months & 6 months & Zero & 3 months & 6 months \\
\hline & \multicolumn{3}{|c|}{$\begin{array}{c}\text { Total bacterial count (TBC) } \\
(\mathrm{cfu} / \mathrm{g})\end{array}$} & \multicolumn{3}{|c|}{$\begin{array}{l}\text { Mold and yeasts } \\
\quad(\mathrm{cfu} / \mathrm{g})\end{array}$} \\
\hline Control (C) & $150 \times 10^{2 \mathrm{aC}}$ & $470 \times 10^{2 \mathrm{aB}}$ & $580 \times 10^{2} \mathrm{aA}$ & $48 \times 10^{2 \mathrm{aC}}$ & $130 \times 10^{2} \mathrm{aB}$ & $290 \times 10^{2} \mathrm{aA}$ \\
\hline $\mathrm{B}_{1}$ & $70 \times 10^{2 \mathrm{bcC}}$ & $320 \times 10^{2 \mathrm{cB}}$ & $530 \times 10^{2 \mathrm{bA}}$ & $22 \times 10^{2 \mathrm{bcC}}$ & $60 \times 10^{2 \mathrm{bcB}}$ & $210 \times 10^{2 \mathrm{bcdA}}$ \\
\hline $\mathrm{B}_{2}$ & $53 \times 10^{2 \mathrm{cdeC}}$ & $300.5 \times 10^{2 \mathrm{cB}}$ & $340 \times 10^{2 \mathrm{dA}}$ & $18 \times 10^{2 \mathrm{bcc}}$ & $60 \times 10^{2 \mathrm{bcB}}$ & $190 \times 10^{2 \mathrm{deA}}$ \\
\hline $\mathrm{B}_{3}$ & $34 \times 10^{2 \mathrm{efg} \mathrm{C}}$ & $250 \times 10^{2}$ deB & $300 \times 10^{2 \mathrm{dA}}$ & $14 \times 10^{2 \mathrm{cB}}$ & $30 \times 10^{2} \mathrm{deB}$ & $170 \times 10^{2 \mathrm{efA}}$ \\
\hline $\mathrm{F}_{1}$ & $80 \times 10^{2 b B}$ & $400 \times 10^{2 \mathrm{bA}}$ & $430 \times 10^{2 \mathrm{cA}}$ & $27 \times 10^{2 \mathrm{bC}}$ & $80 \times 10^{2 b B}$ & $240 \times 10^{2 \mathrm{bA}}$ \\
\hline $\mathrm{F}_{2}$ & $63 \times 10^{2 \mathrm{bcdC}}$ & $260 \times 10^{2 \mathrm{~dB}}$ & $400 \times 10^{2 \mathrm{cA}}$ & $20 \times 10^{2 \mathrm{bcC}}$ & $70 \times 10^{2}$ bcB & $200 \times 10^{2 \mathrm{cdeA}}$ \\
\hline $\mathrm{F}_{3}$ & $41 \times 10^{2 \mathrm{defC}}$ & $160 \times 10^{2 \mathrm{fB}}$ & $330 \times 10^{2 \mathrm{dA}}$ & $17 \times 10^{2} \mathrm{bcC}$ & $50 \times 10^{2 \mathrm{cdB}}$ & $170.5 \times 10^{2 \mathrm{efA}}$ \\
\hline $\mathrm{L}_{1}$ & $150 \times 10^{2} \mathrm{aB}$ & $320 \times 10^{2 \mathrm{cA}}$ & $340 \times 10^{2 \mathrm{dA}}$ & $23 \times 10^{2 \mathrm{bcB}}$ & $30 \times 10^{2 \mathrm{deB}}$ & $230 \times 10^{2 \mathrm{bcA}}$ \\
\hline $\mathrm{L}_{2}$ & $10 \times 10^{2} \mathrm{gB}$ & $220 \times 10^{2 \mathrm{eA}}$ & $230 \times 10^{2 \mathrm{eA}}$ & $18 \times 10^{2 \mathrm{bcB}}$ & $20 \times 10^{2 \mathrm{eB}}$ & $180 \times 10^{2 \operatorname{def} \mathrm{A}}$ \\
\hline $\mathrm{L}_{3}$ & $23 \times 10^{2 \mathrm{fgB}}$ & $120 \times 10^{2 \mathrm{gA}}$ & $130 \times 10^{2 \mathrm{fA}}$ & $16 \times 10^{2} \mathrm{bcB}$ & $20 \times 10^{2 \mathrm{eB}}$ & $150 \times 10^{2 \mathrm{fA}}$ \\
\hline
\end{tabular}

Values bearing the same small letter within the same column (effect of treatments) are not significantly different $(\mathrm{P}>0.05)$

Values bearing the same capital letter within the same row (effect of storage period) are not significantly different $(\mathrm{P}>0.05)$. 
From these results, it could be noticed that, the initial (Zero time) counts of total bacterial, molds and yeasts of the control during the storage period were high $\left(150 \times 10^{2}\right.$ and $48 \times 10^{2} \mathrm{cfu} / \mathrm{g}$ respectively) compared with the other chicken burger samples and addition of caper buds, fruits and leaves powders at 1.5, 2 and $2.5 \%$ to chicken burger formulas lowered the count of microbial load. while prolonged storage period with control sample from 3 to 6 months the total bacterial count, and molds and yeasts counts were increased from $470 \times 10^{2}$ to $580 \times 10^{2} \mathrm{cfu} / \mathrm{g}$ and $130 \times 10^{2}$ to $290 \times 10^{2} \mathrm{cfu} / \mathrm{g}$ respectively. On the other hand, the best effect on retardation the microbial growth was noticed in chicken burger sample prepared using caper leaves powder at level $2.5 \%\left(\mathrm{~L}_{3}\right)$ from 3 months to the end of storage 6 months. It could be concluded that the beneficial effect of caper on extending the shelf-life of burger patties might be due to the presence of flavonoids such as quercetin, hispertin, hisperidin and rutin (Romeo et al., 2015 and Gullon et al., 2016) and phenolic compounds (Gil et al., 2000 and Kharchoufi et al., 2018).

\section{CONCLUSION}

From all results which had been discussed in this study, it could be concluded that, the addition of caper buds, fruits and leaves powders (Capparis spinosa) in different ratios to chicken burger patties had an effective ability of retarding lipid oxidation and inhibiting microbial growth during frozen storage at $-18^{\circ} \mathrm{C}$ for 6 months, also improved the quality parameters of prepared chicken burger patties such as cooking loss, cooking yield, water holding capacity and sensory attributes. Therefore, caper buds, fruits and leaves powders can be considered as an effective natural additive with both antioxidant and antibacterial activities to replace synthetic ones which are used in chicken meat products given their potential to enhance the quality and nutritional value of chicken burger patties.

\section{REFERENCES}

A.O.A.C. 2000. Official Methods of Analysis. 17th ed. of the association of official analytical chemists. Gaithersburg, M. D. USA.

Abd El Haleam, N.Sh. 2009. Chemical and Physical Characteristics of Beef and Vegetarian (Veggie) Burger Served in Some Hotels. Alex. Sci . Exch. J. 30: 406-211.

Akarpat, A., S. Turhan and N.S. Ustun. 2008. Effects of hotwater extracts from myrtle, rosemary, nettle and lemon balm leaves on lipid oxidation and color of beef patties during frozen storage. J. Food Process. Preserv.32:117132.
Alakali, J.S., S.V. Irtwange and M.T. Mzer. 2010. Quality evaluation of beef patties formulated with bambara groundnut (Vigna subterranean L.) seed flour. Meat Sci.85: 215-223.

Ali, M. S., G. D. Kim, H. W. Seo, E. Y. Jung, B. W. Kim, H. S. Yang and S. T. Joo. 2011. Possibility of making lowfat sausages from duck meat with addition of rice flour. Asian-Aust. J. Anim. Sci. 24:421-428.

Al-Juhaimi, F., K. Ghafoor, M. D. Hawashin, O. N. Alsawmahi and E. E. Babiker. 2016. Effects of different levels of Moringa (Moringaoleifera) seed flour on quality attributes of beef burgers. CyTA - J. Food.14: 1-9.

American Public Health Association "APHA" .1976. Compendium of methods for the microbiological examination of food. Speck, M.L. (ed.). Washington, D. C., USA, pp. $542-543$.

Badr, S.A and M. A. El-Waseif . 2 017. Influence of caper (capparis spinosa 1) seeds powder addition as source of bioactive phytochemicals on quality attributes and shelf life extension of beef burger patties. Middle East J. Agric. Res. 6:1243-1258.

Baker, R.C., S.W. Obrian and P.W. Gossett. 1984. Development and evaluation of chicken burger formulations and effect of heating time incorporating underutilized poultry meats. Poultry Sci.63:938.

Basker, D. 1988. Critical values of differences among rank sums for multiple compositions. Food Technol. 42:77, 78, $80,84$.

Cao, G., E. Sofic and R.L. Prior. 1997. Antioxidant and prooxidant behavior of flavonoids: Structure activity relationships. Free Radicals Boil. Med. 22:794-760.

Das, A.K., V. Rajkumar and D.K. Dwivedi. 2011. Antioxidant effect of curry leaf (Murraya koenigii) powder on quality of ground and cooked goat meat. Int. Food Res. J. 18: 563569.

Difco. 1984. Manual of Dehydrated Culture Media and Reagents for Microbiological and Clinical Laboratory Procedures, $9^{\text {th }}$ Ed., Difco Laboratories Inc., Detroit, USA. On-line: http://www.maplica.com/Manual1\%20difco\%20D-G.pdf.

Fernandez-Lopez, M., A. Gomez-Perez and N. Juristo . 1997. Methontology: From Ontological Art Towards Ontological Engineering. Proceedings of the AAAI97 Spring Symposium Stanford, USA.

George, M. E. B and B. W. Berry. 2000. Thawing prior to cooking affects sensory, shear force and cooking properties of beef pattie. J. Food Sci. 65: 2-8.

Gil, M. I., F. A. Tomás-Barberán, B. Hess-Pierce, D. M. Holcroft and A. A. Kader. 2000. Antioxidant Activity of Pomegranate Juice and Its Relationship with Phenolic Composition and Processing. J. Agric. Food Chem. 48:4581-4589.

Gok, V., L. Akkaya, E. Obuz and S. Bulut . 2011. Effect of ground poppy seed as a fat replacer on meat burgers. Meat Sci. 89: $400-404$. 
Gullon, B., M. E. Pintado, J. A Pérez and M. Viuda. 2016. Assessment of polyphenolic profile and antibacterial activity of pomegranate peel (Punica granatum) flour obtained from co-product of juice extraction. Food Control. 59: 94- 98.

Hamm, R. 1986. Functional properties of the myofibrillar system and their measurements, In: Bechtel P. J. (Ed.), Muscle as food, Academic Press Inc., New York, USA, pp. 135-199.

Harold, E., S.K. Ronald and S. Ronald .1987. Pearson's chemical analysis of foods. 8th ed. Longm House, Burnt, M; Harlow, Essex CM 202 JE, England.

Honikel, K. O. 1998. Reference methods for assessment of physical characteristics of meat. Meat Sci. 49: 447-457.

Inocencio, C., D. Rivera, F. Alcaraz and F. A. TomásBarberán. 2000. Flavonoids content of commercial capers (Capparis spinosa, C. sicula and C. orientalis) produced in Mediterranean countries. Eur. Food Res. Technol. 212:70- 74 .

Kanatt, S.R., R. Chander and A. Sharma. 2007. Antioxidant potential of mint (Mentha spicata L.) in radiationprocessed lamb meat. Food Chem.100: 451-458.

Karre, L., K. Lopez and K. J. K Getty. 2013. Natural antioxidants in meat and poultry products. Meat Sci.94: 220-227.

Keshk, S.A., A.M. Abd El-Razek and W.A. Amin .2008. General Characteristics and Storage Stability of Beef Burger Containing Citrus Wastes Mixture. Alex. Sci . Exch. J. 29: 208-216.

Kharchoufi, S., F. Licciardello, L. Siracusa, G. Muratore, M. Hamdi and C. Restuccia.2018. Antimicrobial and antioxidant features of 'Gabsi' pomegranate peel extracts. Ind. Crops Prod. 111: 345-352.

Klangpetch, W., K. Phromsurin, K. Hannarong, J. Wichaphon and S. Rungchang. 2016. Antibacterial and antioxidant effects of tropical citrus peel extracts to improve the shelf life of raw chicken drumettes. Int. Food Res. J. 23: 700707.

Kumar, Y., D.N. Yadav, T. Ahmad and K. Narsaiah. 2015. Recent trends in the use of natural antioxidants for meat and meat products. Comprehensive reviews in food science and food safety.14:796 - 813 .

Madhan, B., V. Subramanian, R. J. Raghava, U. N. Balachandran and T. Ramasami . 2005. Stabilization of collagen using plant polyphenol: Role of catechin. Int. J. Biol. Macromol.37:47-53.

Mansour, E.H and A.H. Khalil. 2000. Evaluation of antioxidant activity of some plant

extracts and their application to ground beef patties. Food Chem.69: 135-141.

McCarthy, T.L., J.P. Kerry, J.F. Kerry, P.B Lynch and D.J. Buckley. 2001. Assessment of the antioxidant potential of natural food and plant extracts in fresh and previously frozen pork patties. Meat Sci. 57: 177-184.
Naveena, B.M., A.R. Sen, R.P. Kingsly, D.B. Singh and N. Kondaiah. 2008. Antioxidant activity of pomegranate rind powder extract in cooked chicken patties. Int. J. Food Sci. Technol .43:1807-1812.

Nissen, L.R., D.V. Byrne, G. Bertelsen and L.H. Skibsted. 2004. The antioxidative activity of plant extracts in cooked pork patties as evaluated by descriptive sensory profiling and chemical analysis. Meat Sci. 68: 485-495.

Oroszvári, B.K., I. Sjohölm and E. Tornberg. 2005. The mechanisms controlling heat and mass transfer on frying beef burgers. 1. The influence of the composition and comminution of meat raw material. J. Food Eng. 67: 499 506.

Pearson, D. 1991. The chemical analysis of food. Churchill: New York, London, pp: 374-410. Afr. J. Food Sci. 3: 316319.

Pettersen, M.K., M.B., Mielnik, T. Eie, G. Skrede and A. Nilsson. 2004. Lipid oxidation in frozen, mechanically deboned turkey meat as affected by packaging parameters and storage conditions. Poultry Sci. 83:1240-1248.

Rather, S. A., F. A. Masoodi, R. Akhter, J. A. Rather and K. A. Shiekh . 2016. Advances in use of natural antioxidants as food additives for improving the oxidative stability of meat Products. Madridge J. Food Technol.1:10-17.

Reihani, S.F.S., Th.C. Tan, N. Huda and M. E. Azhar. 2014. Frozen storage stability of beef patties incorporated with extracts from ulam raja leaves (Cosmos caudatus). Food Chem.155:17-23.

Rodriguez-Ambriz, S., J. Islas-Hernandez, E. AgamaAcevedo, J. Tovar and L. A. Bello-Perez. 2008. Characterization of a fibre-rich powder prepared by liquefaction of unripe banana flour. Food Chem. 107:1515-1521.

Rojas, M.C and M.S. Brewer. 2007. Effect of natural antioxidants on oxidative stability

of cooked, refrigerated beef and pork. Journal of Food Sci.72: 282-288.

Rojas, M.C and M.S. Brewer. 2008. Effect of natural antioxidants on oxidative stability

of frozen, vacuum-packaged beef and pork. J. Food Qual .31: $173-188$.

Romeo, F., G. Ballistreri, S. Fabroni, S. Pangallo, M. Nicosia, L. Schena and P. Rapisarda. 2015. Chemical Characterization of Different Sumac and Pomegranate Extracts Effective against Botrytis cinerea Rots. Molecules. 20: 11941.

Salem, A. M., R.A. Amin and G. S. A. Afifi. 2010. Studies on antimicrobial and antioxidant efficiency of some essential oils in minced beef. J. Am. Sci. 6: 691-700.

Serdaroglu, M and O. Degirmencioglu. 2004. Effects of fat level $(5 \%, 10 \%, 20 \%)$ and

corn flour $(0 \%, 2 \%, 4 \%)$ on some properties of Turkish type meatballs (koefte). Meat Sci . 68: 291-296.

Shah, M. A., S. J. D. Bosco and S. A. Mir. 2014. Plant extracts as natural antioxidants in meat and meat products. Meat Sci. 98: 21-33. 
Steel, R. G. D and J. H. Torrie. 1980. Principles and procedures of statistics. London: McGraw 326 Hill.

Swain, T and W.E. Hillis .1959. The phenolic constituents of Prunes domestical- the quantitative analysis of phenolic constituents. J. Sci. Food Agric. 10: 63-68.

Taludkar, S and D.P. Sharma, 2009. Development of dietary fiber rich chicken meat patties using wheat and oat bran. J. Food Sci. Technol. 47: 224-229.

Tlili, N., A. Khaldi, S. Triki and S. Munné-Bosch. 2010 Phenolic compounds and vitamin antioxidants of caper (Capparis spinosa). Plant Foods Hum. Nutr. 65: 260-265.

Weiss, J., M. Gibis, V. Schuh and H. Salminen. 2010. Advances in ingredient and processing systems for meat and meat products. Meat Sci. 86:196-213.
Wojciak K.M., Z.J. Dolatowski and A. Okon. 2011. The effect of water plant extracts addition on the oxidative stability of meat productsActa Sci. Pol. Technol. Aliment.10: 175188.

Wong, W.C., C.F. Pui, R. Tunung, Y.K. Cheah, Y. Nakaguchi, M. Nishibuchi and R. Son .2012. Prevalence of Listeria monocytogenes in frozen burger patties in Malaysia. Int. Food Res. J.19:1751-1756

Zaki, N., H. Abdelmalek, O. Aaziz and P.F. Juan. 2013. Quality characteristics of Moroccan sweet paprika (Capsicum annuum L.) at different sampling times. Food Sci. Technol. 33: 577-585.

Ziprin, Y.A., K.S. Rhee, Z.L. Carpenter, R.L. Hostetler, R.N. Terrell and K.C. Rhee. 1981. Glandless,cotton-seed peanut and soy protein ingrediants in ground beef patties: Effect on rancidity and the other quality factors. J. Food Sci. 46: 58-64.

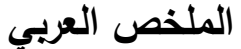

\section{تأثير إضافة براعم وثُمار وأورلق اللصف فى جودة أقراص برجر الاجاج المجمة هند سعد أبوشامة}

حمض الثيوبيوتريك اثتاء التخزين علي- 18 درجة مئوية لمدة ستة أشهروذللك بزيادة معدلات الاضافة لكل اجزاء نبات اللصف في جميع المعاملات محل الدراسة مقارنة

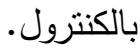

لذلك فان هذه الدراسة توصى بالاستفادة من اجزاء اللصف (البراعم والثماروالأوراق) فى تصنيع برجر الاجاج كأضافات غذائية طبيعية مضادة للأكسدة والنمو الميكروبي بدلا" من استخدام المضادات الكيمائية المصنعة والمستخدمة في منتجات اللجوم كماإنها تعمل على تحسين الجودة الحسية والتغذوية لهذه المنتجات.

الكلمات المفتاحية: اللصف ، اقراص برجر الاجاج ، خصائص الجودة.
الهدف من البحث انتاج برجر الاجاج باضافة تركيزات مختلفة من مساحيق براعم وثمار واوراق اللصف ( 0, ا، r، \% \% \%). وقد تم دراسة تأثيرهذه الإضافات علي عينات برجر الدجاج المنتجة اثناء التخزين بالتجميد علي - 1 أدرجة مئوية لمدة 7 أثنهر وأظهرت النتائج التي نم الحصول عليها ان أجزاء اللصف من براعم وثماروأوراق كانت غنية فى محتواها من الفينولات الكلية كما يمكن اعتبارها مصدرا" جيدا" للبروتين والدهون والرماد والألياف الخام والكربوهيدرات. كما أن إضافة مسحوق كلا من براعم اللصف والثمار والأوراق إلي برجر الاجاج أدي إلي تحسين الجودة الفيزيائية منل تقليل فقدان الطهى والإنكماش وزيادة القدرة علي الإحتفاظ بالماء وانتاجية الطهى وأظهرت خصائص حسية جيدة (WHC) وقبول أفضل. وعلاوة علي ذللك،حدوث تثبيط للنمو الميكروبى وتعزيز الثبات الأوكسيدي لبرجر الاجاج حيث انخفضت قيم 